\title{
MODEL RUMAH HARAPAN MELALUI PENINGKATAN PARTISIPASI ANAK DI LKSA DANA MULIA KOTA BANDUNG PROVINSI JAWA BARAT
}

\author{
Junaidi \\ Politeknik Kesejahteraan Sosial Bandung \\ Email: junaidimeulaboh88@gmail.com \\ Ellya Susilowati \\ Politeknik Kesejahteraan Sosial Bandung \\ Email: ellyasusilowati1@gmail.com
}

\begin{abstract}
Children's participation is a right that must be fulfilled, including for children who are cared for in alternative care institutions. The purpose of this research is to design a development model for children's participation in determining children's activities related to institutional services at the Dana Mulia Child Welfare Institution (LKSA). The research method uses secondary data analysis with a qualitative approach on child participation, this method is used because it was carried out during the lock down policy. The results of the study found that children's participation in determining their activities in institutions was still limited, elementary school-aged children were not included and their opinions were not asked about the rules and services related to their lives in LKSA. From the results of the study, a model for increasing children's participation was designed. This model is called the Expectation model which has been refined through the results of discussions with experts. The Rumah Harapan model will be used as a reference for policy makers that can be applied in all childcare institutions related to the implementation of child participation. The implementation of this model requires monitoring from institutional administrators, social workers so that this model can be widely understood, so that implementation carried out in care institutions will feel easy. This model is recommended as a reference in the application of participation rights in alternative child care institutions, especially those who take care of children of elementary school age.
\end{abstract}

\section{Keywords: Child Participation, Child Rights, Child Welfare Institutions, Children's Basic Needs, Children's Protection}

\begin{abstract}
Abstrak
Partisipasi anak merupakan hak yang harus dipenuhi termasuk bagi anak yang diasuh di lembaga pengasuhan alternatif. Tujuan penelitian ini adalah membuat rancangan pengembangan model partisipasi anak dalam menentukan aktivitas anak terkait dengan layanan kelembagaan di Lembaga Kesejahteraan Sosial Anak
\end{abstract}


(LKSA) Dana Mulia. Metode penelitian menggunakan analisis data sekunder dengan pendekatan kualitatif tentang partisipasi anak, metoda ini digunakan karena dilakukan pada masa kebijakan lock down. Hasil penelitian ditemukan bahwa partisipasi anak dalam menentukan aktivitas mereka di lembaga masih terbatas, anak usia SD tidak diikut sertakan dan tidak diminta pendapatnya terkait dengan aturan dan layanan yang berkaitan dengan kehidupan mereka di LKSA. Dari hasil penelitian kemudian di rancang model peningkatan partisipasi anak. Model ini dinamakan model Rumah Harapan yang telah disempurnakan melalui hasil diskusi dengan expert. Model Rumah Harapan ini akan dijadikan suatu acuan bagi pembuat kebijakan yang dapat diterapkan di seluruh lembaga pengasuhan anak terkait dengan penerapan partisipasi anak. Penerapan model ini perlu pemantauan dari para pengurus lembaga, pekerja sosial supaya model ini dapat dipahami secara luas, sehingga implementasi yang dijalankan di lembaga pengasuhan akan terasa mudah. Model ini direkomendasikan menjadi acuan dalam penerapan hak partisipasi pada lembaga pengasuhan alternatif anak, terutama mereka yang mengasuh anak-anak yang berusia sekolah SD.

Kata Kunci: Partisipasi, Hak Anak, Lembaga Kesejahteraan Sosial Anak, Kebutuhn Dasar Anak 


\section{PENDAHULUAN}

Pengasuhan berbasis Lembaga Kesejahteraan Sosial Anak (LKSA) merupakan alternatif terakhir untuk anak-anak yang tidak bisa diasuh di dalam keluarga inti, keluarga besar, kerabat, atau keluarga pengganti (Permensos No. 30 tahun 2012). Sebagai pengganti oramgtua, LKSA wajib memenuhi semua hak anak, termasuk hak partisipasi. Konvensi Hak Anak pada pasal 12 menyatakan bahwa anak-anak memiliki hak untuk berpartisipasi dalam hal-hal yang berdampak signifikan pada kehidupan mereka termasuk dalam melakukan aktivitasnya di LKSA. Partisipasi berkaitan dengan kemampuan anak anak menyatakan pandangannya secara bebas tentang segala hal yang mempengaruhi anak. Pandangan anak disesuaikan dengan usia anak (Borgne, C. L., \& Tisdall, E. K. 2017)

Jumlah anak terlantar di Indonesia yang dilaporkan Direktur Kesejahteraan Sosial Anak dalam paparannya berjumlah 64.053 anak. Sebagian besar anak terlantar tersebut diasuh dalam pengasuhan alternatif di Lembaga Kesejahteraan Sosial Anak. Hasil penelitian tentang pengasuhan anak di LKSA ditemukan adanya pelanggaran hak anak, termasuk hak partisipasi (Save The Children, 2007). Dimana anak-anak tidak dapat berpendapat menentukan pilihannya terkait dengan aspek-aspek dalam kehidupan sehari-hari seperti menentukan pilihan sekolah, makanan dan penentuan jadwal aktivitas di panti.

Pengaturan pengasuhan alternatif telah diatur oleh Permensos 30/HUK/2011 tentang Standar Nasional Pengasuhan Anak di LKSA (Susilowati, E., Dewi, K., \& Kartika, T. 2019). Pada peraturan tersebut di BAB IV C yang membahas tentang pelayanan anak berbasis lembaga di point 8 tentang partsisipasi anak dibahas tentang suara anak dan pilihan anak di lembaga. Penerapan tentang suara anak disebutkan 3 ayat yaitu : (1) Lembaga Kesejahteraan Sosial Anak harus mendorong anak untuk menyampaikan pendapat dan ikut serta dalam membahas berbagai hal penting yang menyangkut kepentingan mereka, antara lain dalam penyusunan dan pelaksanaan aturan untuk penegakan disiplin, memberikan masukan bagi pelayanan Lembaga Kesejahteraan Sosial Anak, serta dalam perencanaan dan pengambilan keputusan pengasuhan, termasuk berapa lama anak akan tinggal dalam Lembaga Kesejahteraan Sosial Anak dan tujuan dari penempatan anak.: (2) Lembaga Kesejahteraan Sosial Anak harus menyediakan kesempatan, informasi dan lingkungan yang aman dan kondusif agar anak dapat menyampaikan pendapat dan ikut serta dalam pembahasan-pembahasan berbagai hal penting tersebut ; (3) Keputusan yang diambil dalam Lembaga Kesejahteraan Sosial Anak, baik yang terkait dengan kehidupan sehari-hari anak harus mencerminkan suara, ide dan pendapat anak(Kepmesos, 2011).

Partisipasi anak di rumuskan oleh UNICEF (2003) dilakukan dengan tahapan berikut: ) anak-anak mengambil bagian dalam mempengaruhi proses keputusan dan kegiatan mereka; 2) Orang dewasa mendengarkan dan memperhatikan: 3) anak-anak mengartikulasikan pandangan dan keprihatinan mereka sendiri; 4) anak-anak mengambil bagian dalam perencanaan, pengelolaan, pelaksanaan, dan evaluasi mereka: 5) anakanak yang terlibat dalam pengambilan keputusan: 6) anak-anak memulai dan mengambil tanggung jawab dalam proses tersebut. Konsep ini sejalan dengan teori yang sering digunakan tentang model partisipasi anak adalah model Hart (2002) yang menggambarkan tingkat partisipasi pada anak ( 
Borgne, C. L., \& Tisdall, E. K. 2017; ).

Salah satu lembaga yang menerapkan Standar Nasional Pengasuhan Anak adalah Lembaga Kesejahteraan Sosial Anak (LKSA) Dana Mulya Bandung. Sejarah LKSA Dana Mulia telah dimulai sejak tahun 1948, dan akan terus berlanjut sampai maksud, kesaksian, dan kehendak-Nya terpenuhi. Sejarah ini dapat kita pahami dalam kerangka tiga masa kehidupan yang telah dilalui, yaitu masa pendirian, masa pembentukan visi, dan masa pengembangan pelayanan. Lembaga ini memiliki dua asrama yaitu Asrama Putra berlokasi di Jl. Pasteur 17 (sekarang Jl. Pasteur no 12) Bandung dan Asrama Putri di jalan Ir. H. Juanda 33 Bandung. Pada masa pendirian tersebut, seluruh pengeluaran untuk membiayai Panti Asuhan menjadi tanggungan pengurus, dan upaya dari Ibu Asrama melalui usaha menjual kecap. Visi lembaga ini adalah Menjadi berkat dengan mendidik, membina dan membangun kepribadian/karakter anak-anak asuh sehingga mereka mempunyai integritas dan mandiri dalam menyongsong masa depan". Jumlah anak yang diasuh di Asrama putera terdapat 20 anak laki-laki dan 15 orang anak perempuan.

Karena sudah menerapkan SNPA, lembaga telah menerapkan aspek-aspek dalam pengasuhan alternatif yang diatur dalam SNPA termasuk diantaranya adalah penerapan partisipasi anak. Hasil asesmen pada saat dilakukan praktikum di lembaga ditemukan bahwa penerapan pemenuhan hak partisipasi anak sudah dilakukan diantaranya dalam pembuatan peraturan selama anak masih menetap di LKSA. Tujuan keterlibatan ini demi kenyamanan anak menjalankan semua aktivitas, baik di dalam lembaga maupun di luar.

Namun demikian, masih dikeluhkan ada beberapa anak-anak yang sering melakukan tindakan-tindakan melanggar peraturan dalam melakukan aktivitasnya di Lembaga. Pelanggaran itu diantaranya mereka tidak mempedulikan kewajiban-kewajiban yang mesti dijalankan di asrama, seperti tidak melaksanakan piket dan tidak mengerjakan tugas sekolah. Selain itu mereka juga suka membangkang terhadap peraturan yang telah disepakati dan mereka tidak mau diatur serta ingin sesuai dengan kemauan mereka sendiri. Hal ini disebabkan bahwa peraturan yang disepakati tetap hasrus mengacu pada aturan lembaga yang menurut mereka sangatlah ketat. Beberapa masalah lainnya yang ditemukan di LKSA Dana Mulia, seperti: tidak disiplin, membangkang, merokok, perundungan dan sulit diatur. Hal tersebut mengindikasikan bahwa penerapan partisipasi masih belum optimal. Intervensi yang dilakukan pada saat praktikum adalah meningkatkan partisipasi anak dalam membuat peraturan lembaga. Namun demikian pada penyusunan model tersebut masih belum memperhatikan keterlibatan anak berdasarkan usia. Sehingga peraturan yang dibuat berdasarkan partisipasi belum mengakomodasi kebutuhan anak yang lebih kecil atau usia SD. Anak-anak yang lebih dominan pada saat itu lebih pada anak remaja. Sementara di lembaga masih ada lima orang anak SD yang memiliki hak untuk menyampaikan suaranya.

Berdasarkan latar belakang tersebut maka penulis melakukan penelitian "Model Partisipasi Anak terhadap Aktivitas Kelembagaan di LKSA Dana Mulia.”. Alasan penulis melakukan penelitian ini yaitu penulis mencoba merancang sebuah model bagaimana partisipasi anak dalam menjalankan peraturan dengan usia yang berbeda, adapun fokus dalam penelitian ini yaitu pelibatan anak-anak yang masih berusia SD yang diasuh di LKSA Dana 
Mulia yang memerlukan aturan khusus yang dijalankan sesuai dengan kebutuhan dan kapasitas mereka.

\section{METODE}

Penelitian ini dilakukan pada saat berlakunya kebijakan lock down, sehingga metoda yang digunakan adalah penggunaan metode analisis Data Sekunder. Heaton dalam Andrews (2012:12) menyatakan bahwa analisis data sekunder merupakan suatu strategi penelitian yang memanfaatkan data kuantitatif ataupun kualitatif yang sudah ada untuk menemukan permasalahan baru atau menguji hasil penelitian terdahulu. Proses yang dilakukan dalam penelitian ini adalah:

1. Menetapkan sumber data/informasi tentang partisipasi anak pengasuhan alternatif di LKSAk.

2. Mengumpulkan data yang sudah tersedia berkaitan dengan laporan hasil praktikum tentang program partisipasi anak di LKSA

3. Menormalisasikan data dari berbagai sumber setara mungkin "menjadi satu bentuk yang sama").

4. Menganalisis data dengan memetakan datadata atau membandingkan berbagai peraturan maupun model-model yang berkaitan dengan partisipasi anak di LKSA.

Teknik pengumpulan data dalam penelitian ini adalah menggunakan studi dokumentasi, yaitu dengan cara mempelajari data sekunder yang dilakukan penelitian terdahulu. Studi dokumentasi digunakan untuk memperoleh data dan informasi berupa catatan tulisan maupun gambar yang berkaitan dengan partisipasi anak di LKSA Dana Mulia Kota Bandung Provinsi Jawa Barat.

Studi dokumentasi ini bertujuan agar peneliti dapat memahami permasalahan secara menyeluruh. Dokumen yang diperoleh melalui teknik studi dokumentasi meliputi profil LKSA Dana Mulia, SOP LKSA dan kegiatankegiatan rutinitas kelembagaan termasuk peraturan.

Wawancara mendalam (in-depth interview) dilakukan untuk menggali informasi secara langsung dan mendalam melalui telepon degan para pengasuh dan anak-anak di LKSA Dana Mulia. Pertanyaan yang diajukan meliputi jenis peraturan yang sudah diterapkan, pelaksanaan peraturan, hal yang disukai dari peraturan yang sudah ditetapkan serta peraturan yang tidak disenangi anak-anak LKSA Dana Mulia. Termasuk anak-anak usia SD. Tujuan akan dilakukannya wawancara mendalam (in-depth interview) yaitu untuk mendapatkan informasi secara terpadu dari anak-anak.

Pemerikasaan keabsahan data dilakukan dengan Uji kepercayaan (credibility), Uji keteralihan (transferability), Uji ketergantungan (dependability), dan Uji kepastian (confirmability).

Uji kepercayaan (credibility) dilakukan untuk mengetahui kebenaran hasil penelitian yang berkaitan dengan tingkat partisipasi anak dalam kelembagaan LKSA Dana Mulia Kota Bandung Jawa Barat. Penelitian dalam menguji kebenaran dan data yang diperoleh menggunakan beberapa alat penguji, antara lain sebagai berikut :

1. Perpanjangan pengamatan dilakukan untuk mengetahui kebenaran data yang peneliti dapatkan dari subyek sekunder terkait denga partisipasi anak dalam kelembagaan LKSA Dana Mulia. Peneliti melakukan pengecekan kembali pada sumber data asli atau sumber data lain secara mendalam sehingga diperoleh data yang pasti kebenarannya. 
2. Meningkatkan ketekunan peneliti melakukan pengkajian lebih rinci secara berkesinambungan pada saat melakukan studi dokumentasi.

Uji kepastian (confirmability) mirip dengan uji ketergantungan (dependability) yaitu sama-sama menguji proses dari hasil penelitian mengenai Partisipasi Anak dalam Kelembagaan di LKSA Dana Mulia. Uji kepastian (confirmability) digunakan untuk menguji hasil penelitian yang dikaitkan dengan proses yang dilakukan oleh peneliti di lapangan. Apabila hasil penelitian yang dilaporkan oleh peneliti merupakan fungsi dari proses penelitian yang dilakukan maka penelitian tersebut dapat dikatakan sudah memenuhi standar.

Pada analisis model, peneliti melakukan Expert Judgment, yaitu penilaian yang dilakukan oleh ahli (expert) terhadap desain baru yang peneliti rancang terkait Partisipasi Anak di LKSA Dana Mulia. Masukan dari ahli terhadap desain baru selanjutnya akan peneliti gunakan untuk menyusun penyempurnaan model, sehingga didapatkan model akhir bagaimana tingkat partisipasi anak Terhadap Aktivitas kelembagaan di LKSA Dana Mulia Kota Bandung Provinsi Jawa Barat.

\section{HASIL}

\section{Program pelayanan}

LKSA Dana Mulya semula adalah "Panti Asuhan Kristen Dana Mulia" yang diselenggarakan melalui Yasasan Panti Asuhan Kristen Dana Mulia dengan sebutan singkat YPAK Dana Mulia. Yayasan ini menaruh perhatian pada pelayanan Panti Asuhan. Visi dari LKSA Dana Mulya adalah

1. "Menjadi berkat dengan mendidik, membina dan membangun kepribadian/karakter anak-anak asuh sehingga mereka mempunyai integritas dan mandiri dalam menyongsong masa depan”. Misi lembaga adalah:

(1)Mengarahkan dan mendampingi anakanak asuhan/binaan supaya dapat hidup seturut dengan firman Tuhan.

(2)Membantu menolong dan berusaha untuk mmemenuhi kebutuhan hidup anak asuhan/binaan misalnya dalam hal papan, pangan, sandang serta pendidikan yang layak.

(3)Memotivasi, memfasilitasi dan memberi semangat anak-anak asuhan/binaan untuk meraih cita-cita demi masa depan mereka.

Lembaga ini mengasuh anak di dua asrama yang terdiri dari asrama putra dan putri. Asrama putra terdiri dari 20 orang anak asuh dan memiliki 2 orang pengasuh dan asrama putri yang terletak di sebelahnya asrama putra memiliki anak asuh sebanyak 15 orang yang masing-masing memiliki 2 pengasuh.

Program pelayanan yang dilakukan LKSA Dana Mulia dapat dikategorikan dalam empat pelayanan sosial bagi anakanak. Pelayanan ini yang sudah berlangsung sejak awal, dan LKSA Dana Mulya juga terus berusaha untuk memperbaiki meningkatkan mutu pelayanannya baik dari segi kualitas maupun kuantitasnya sehingga LKSA tersebut juga telah mendapatkan apresiasi dari pemerintah dengan mendapatkan nilai Akreditasi 'A'.

Program pelayan yang diberikan yaitu

(1) Pelayanan kebutuhan dasar berupa pemenuhan kebutuhan makanan, pakaian, dan pengasramaan:

(2) Pelayanan kebutuhan pendidikan yaitu disesuaikan dengan minat dan kemampuan anak. Sehingga anak 
bersekolah di luar lembaga sesuai dengan pilihan anak .

(3) Pelayanan kebutuhan kesehatan dimana apabila jika anak dalam keadaan sakit maka akan diberikan pengobatan maupun perawatan yang intensif .

(4) Pelayanan kebutuhan spiritual, rekreasi dan kebutuhan bermain

Dari program pelayanan tersebut bahwa LKSA telah melakukan pemenuhan kebutuhan dasar anak, dan untuk kebutuhan pengasuhan terdapat pengasuh baik untuk anak laki-laki dan anak perempuan sesuai dengan SNPA yaitu 1 pengasuh : 5 anak. Juga tersedia pekerja Sosial yang membantu untuk penanganan permasalahan anak.

2. Kondisi awal dan Kelemahan Model Partisipasi Anak dalam Lembaga

Kondisi awal partisipasi anak dalam lembaga hanya menjalankan peraturan yang sudah ditetapkan LKSA baik untuk anak asuh putra maupun anak asuh putri. Pelibatan anak lebih pada anak SMA dan hanya merupakan beberapa orang saja. Peraturan yang telah disusun berlaku bagi anak-anak asuh semuanya tanpa mempertimbangkan usia anak, padahal masih terdapat anak yang masih bersekolah SD yang memiliki kebutuhan dan kapasitas berbeda. Penyusunan peraturan terkait dengan kehidupan anak juga masih merujuk pada peraturan lembaga yang telah berlaku lama sehingga kurang mereview sesuai dengan kondisi perkembangan anak. Hal ini terbukti dengan berbagai perilaku anak yang peneliti dapatin pada saat praktikum, banyak anak-anak membangkang, memberontak dengan pengasuh, mogok makan bahkan ada diantara mereka yang melawan pengasuhnya sendiri. Masalah lain yang peneliti temui di lembaga yaitu sistem pemberian kegiatan yang sangat tegas tanpa ada diskusi antara anak dan pengasuh misalnya, pemberian tugas dalam membelanjakan sesuatu ke pasar " besok yang akan belanja si A dengan si B, ke pasar C, kalian pergi jam sekian dan pulangnya jam sekian, jika terlambat maka kalian akan mendapatkan sanksi seperti ini", padahal kegiatan seperti ini sangat berbahaya bagi anak terutama bagi anak-anak yang masih berusi di bawah 10 Tahun, Dari pernyataan ini peneliti dapat berasumsi bahwa seorang pengasuh di lembaga itu memiliki wewenang penuh terhadap anak asuhnya, meskipun secara aturan itu hal yang wajar tapi belum tentu anak-anak mampu menjalankan hal tersebut setiap menerima perintah dari pengasuhnya sendiri terutama bagi anak-anak yang masih sekolah SD.

\section{Model Awal Peningkatan Partisipasi Anak}

Pada saat praktikum, penulis melakukan intervensi peningkatan partisipasi anak di LKSA, yaitu dengan mengajak anak untuk melakukan penyusunan aturan terkait dengan kegiatan/aktivitas anak dalam lembaga.

Kelemahan model awal yang diterapkan adalah bahwa partisipasi anak masih di dominasi anak yang yang lebih besar, sehingga peraturan yang dibuat belum mengakomodasi anak yang kecil. Praktikan juga kurang memberikan kesempatan pada anak dengan usia kecil.

\section{Rancangan Model Partisipasi Anak}

Hasil akhir dalam penelitian ini menemukan Rancangan model partisipasi yang dinamakan dengan model "Rumah Harapan'. Model ini diharapkan dapat memberi kenyamanan bagi setiap anak dalam setiap aktivitas kelembagaan di LKSA Dana Mulia yang sudah mengakomodasi anak berdasarkan usia sekolah. Maka dengan adanya model Rumah Harapan ini diharapkan dapat menjadi rulemodle bagi LKSA lain serta menjadi suatu 
masukan bagi pemangku kebijakan untuk mendapatkan standarisasi penerapan partisipasi dalam pelayanan anak di seluruh Indonesia. Upaya ini tentu butuh pembenahan lebih lanjut serta harus melibatkan instansi terkait untuk mempertimbangkan serta menetapkan kebijakan untuk mewujudkan harapan yang tepat untuk anak asuh di lingkungan LKSA.

Langkah-langkah kegiatan dapat dilakukan dengan bagan berikut ini

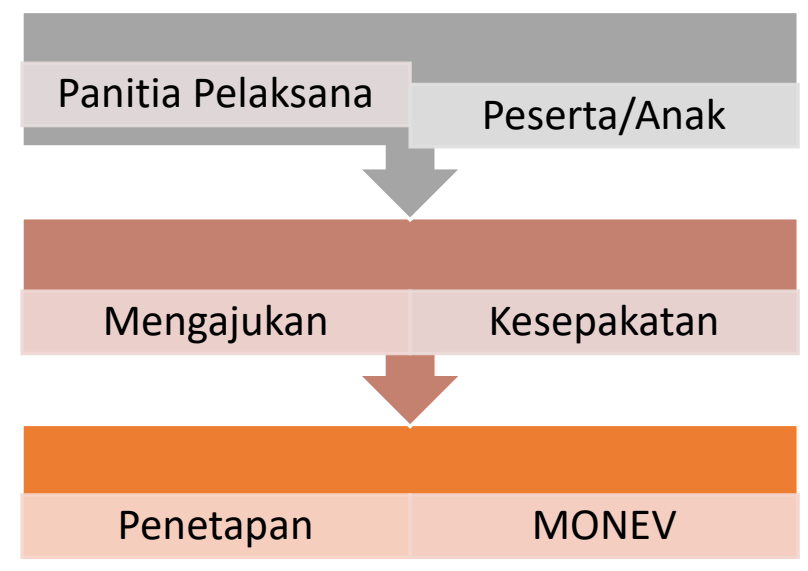

Gambar 1. Tahapan Penyusunan Model

Dari bagan tersebut kemudian dilakukan Expert Judgment agar upaya rancangan model ini tidak terlepas dari masukan-masukan yang diberikan oleh Expert, peneliti terus berdiskusi untuk mendapatkan penyempurnaan dalam merancang model yang bisa diterapkan di LKSA anak dengan mempertimbangkan kelebihan dan kekurangannya. Model Rumah Harapan ini menjadi suatu alternatif bagi lembaga pengasuhan anak demi terciptanya pemenuhan-pemenuhan yang harus diberikan kepada anak, selain itu model ini juga diharapkan akan mengatur segala kebutuhan anak yang masih usia sekolah SD untuk dapat diberlakukan disetiap lembaga pengasuhan anak. Expert juga menyarankan agar model ini akan menjadi masukan-masukan untuk penyempurnaan peraturan menteri No. 30 tahun 2011 tentang standar pengasuhan anak untuk lembaga kesejahteraan sosial anak, khususnya dalam pembahasan partisipasi anak. Selain itu Expert juga menyarankan untuk memberi penguatan kapasitas untuk setiap pengrus khususnya yang menangani anak anak di LKSA Dana Mulia demi demi terciptanya sinergitas antara program dan pihak yang menjalankan program.

Model akhir yang dirancang dalam penelitian ini merupakan hasil yang didapatkan berdasarkan proses penerapan program yang sudah dilakukan serta hasil penyempurnaan dari penilaian-penilaian dari expert. model Rumah Harapan ini akan dijadikan suatu acuan bagi pembuat kebijakan yang dapat diterapkan di seluruh lembaga pengasuhan anak. penerapan model ini tidak terlepas dari pemantauan para pengrus lembaga, pekerja sosial supaya model ini dapat dipahami secara luas, sehingga implementasi yang dijalankan di lembaga pengasuhan akan terasa mudah. Pada akhirnya model ini akan menjadi sebuah standarisasi pengasuhan anak terutama anakanak yang masih berusia sekolah SD yang diasuh di LKSA Dana Mulia, gambar berikut alur pelaksanaan model partisipasi anak di LKSA Dana Mulia;

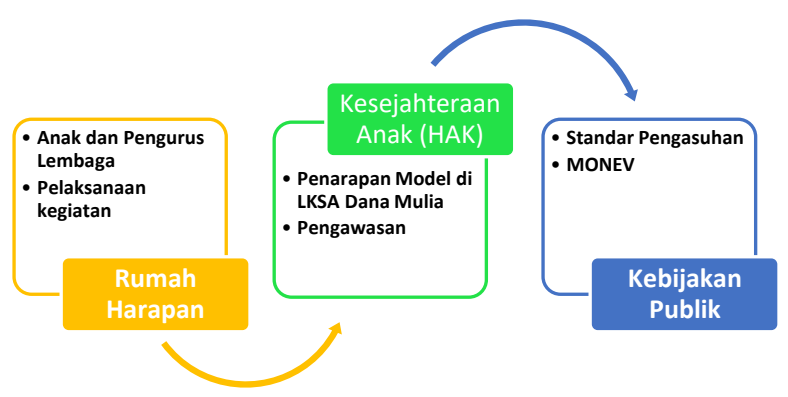

Gambar 2. Model partisipasi anak yang ditetapkan dengan nama Rumah Harapan 
Pada gambar 2 dapat dijelaskan bahwa dalam pelaksanaan peningkatan partisipasi anak melalui Rumah Harapan:

1. Adanya komunikasi timbal balik antara anak dengan pengurus terkait dengan aktivitas di lembaga. Orang dewasa dalam lembaga juga meu mendengarkan.

2. Pelaksanaan kegiatan difasilitasi oleh Pekerja Sosial

3. Pelaksanaan model di monitor bersama anak dengan diskusi terbuka

4. Partisipasi anak memperhatikan kapsitas dan suara anak.

\section{PEMBAHASAN}

Partisipasi anak merupakan hak yang haris dipenuhi oleh semua anak termasuk anak dalam pengasuhan alternatif. Pentingnya partisipasi anak berkaitan prinsip-prinsip hak anak lainnya yaitu kepentingan terbaik anak dan non diskriminasi baik anak yang kecil maupun anak yang dewasa (Ellya Susilowati, 2021). Hasil penelitian telah ditemukan bahwa LKSA dengan akreditasi A telah menerapkan standar pelayanan bagi anak termasuk penerapan partisipasi anak. Namun demikian, LKSA belum menerapkan implementasi partisipasi seperti dimuat pada bab IV C point 8 Pemensos 30/HUK/2011, yaitu memfasilitasi anak untuk menyampaikan pendapat dan ikut serta dalam membahas berbagai hal penting yang menyangkut kepentingan mereka, antara lain dalam penyusunan dan pelaksanaan aturan untuk penegakan disiplin, memberikan masukan bagi pelayanan.

\section{Partisipasi berdasarkan kapasitas anak.}

Model yang dibangun untuk meningkatkan partisipasi oleh pekerja sosial juga perlu memperhatikan kapasitas dan usia anak
(Borgne, C. L., \& Tisdall, E. K. 2017; Tali_Gal_International_Perspectives_and_Em pirical. (n.d.).,2015). Hal ini perlu menjadi perhatian yang penting bagi pemangku kebijakan untuk menetapkan kebijakan baru terkait dengan partisipasi anak dalam lembaga pengasuhan anak. Apabila hali ini tidak dilakukan akan terdapat permasalahan anak seperti terbukti dari hasil penelitian yaitu adanya perilaku anak yang menggagu dalam proses pelayanan. Bentuk untuk adanya partisipasi adalah seperti dikemukakan dalam Peraturan Menteri Pemberdayaan Perempuan dan Perlindungan Anak Republik Indonesia Nomor 3 Tahun 2011, tentang Kebijakan Partisipasi Anak bahwa "Setiap anak berhak untuk berpartisipasi secara wajar dan berhak menyatakan dan didengar pendapatnya serta memberikan informasi sesuai dengan tingkat kecerdasan dan usianya.

Partisipasi berdasarkan kapasitas usia dapat dilakukan dengan memperhatikan kebutuhan dari tingkat perkembangan anak. Pada setiap tahap perkembangan anak terdapat tingkat kebutuhan anak, misalnya untuk anak usia dibawah enam tahun akan berbeda dengan usia 6 - 12 tahun dan akan berbeda juga dengan tahapan usia 12- 18 tahun.

Kelemahan model awal dari hasil pengamatan dan wawancara peneliti pada saat melakukan praktikum, selama ini belum ada kebijakan khusus yang diberlakukan pada setiap lembaga pengasuhan anak terkait partisipasi anak dalam penetapan peraturan pengasuhan. Sebenarnya hak berpartisipasi ini harus dijalankan diberbagai lingkungan anak dalam keluarga, hak partisipasi anak dalam lingkungan masyarakat bahkan hak partisipasi anak dalam pembangunan dst. Dalam Lembaga Pengasuhan Anak belum adanya suatu kebijakan khusus yang mengatur terkait hak 
partisipasi anak dalam kegiatan kelembagaan, padahal segala sesuatu yang berlaku di lembaga kesejahteraan sosial anak adalah semata-mata demi kepentingan dan pemenuhan hak anak untuk mendapatkan hak-haknya. Namun pada kenyataannya di lembaga pengasuhan anak khususnya di LKSA Dana Mulia sendiri belum adanya suatu gagasan khusus yang mengatur tentang penetapan peraturan harus melibatkan anak secara langsung serta membuat aturan khusus bagi anak-anak yang masih di bawah umur, jika hal ini tidak dilakukan maka masalah yang timbul yaitu adanya kesenjangan antara pengasuh dan anak asuh dalam menjalankan aktivitas kelembagaan.

Merujuk pada standar pengasuhan anak empat prinsip dalam perlindungan hak anak yang menjadi dasar bagi rumusan standar, yaitu:

1. Non diskriminasi. Semua bentuk pelayanan berkaitan dengan pengasuhan baik di dalam keluarga, keluarga pengganti maupun Standar Nasional Pengasuhan Untuk Lembaga Kesejahteraan Sosial Anak 11 melalui Lembaga Kesejahteraan Sosial Anak dilaksanakan tanpa diskriminasi, dari sisi usia, jenis kelamin, ras, agama dan budaya, dan bentuk diskriminasi lainnya.

2. Kepentingan terbaik anak. Kepentingan terbaik anak menjadi prioritas dalam pelayanan yang dilakukan oleh semua pihak yang bekerja dalam pengasuhan anak.

3. keberlangsungan hidup dan perkembangan. Upaya untuk mencari solusi pengasuhan dilakukan dengan memperhatikan perkembangan anak sesuai usia mereka masing-masing.

4. Partisipasi. Keputusan tentang pengasuhan anak dilakukan semaksimal mungkin dengan melibatkan partisipasi anak, sesuai dengan kapasitas mereka dan kapan pun anak mau. (https://jdih.kemenpppa.go.id/)

Maka dari itu lembaga wajib memberikan kesempatan kepada anak asuh untuk bisa ikut terlibat langsung dalam pengambilan keputusan dan penetapan peraturan yang sesuai dengan kebutuhan dan usia anak.

\section{Model Rumah Harapan}

Model rumah harapan merupakan model yang dibangun dengan memenuhi langkahlangkah dalam menerapkan partisipasi anak. Penerapan partisipasi yaitu menfasilitasi suara dan pilihan anak terkait dengan kehidupan anak di dalam lembaga. Aspek-aspek yang dibangun dalam partisipasi anak dalam lembaga seperti teori yang dikemukakan Rogger Hart (dalam Borgne, C. L., \& Tisdall, E. K. 2017) tentang Ladder of Participation, yaitu bahwa partisipasi yang baik yaitu anak-anak melakukan inisiasi dengan orang dewasa dan orang dewasa mendengarkan dan melakukan diskusi dengan anak. Sehingga partisipasi bukan sekedar 'manipulasi' yaitu anak-anak melakukan atau mengatakan apa yang orang dewasa ingin mereka lakukan tetapi tanpa pemahaman yang nyata tentang masalah tersebut. Anak-anak ditanya apa yang mereka pikirkan, orang dewasa menggunakan beberapa ide tetapi tidak memberi mereka umpan balik tentang pengaruh ide-ide tersebut terhadap keputusan yang dibuat (Hart, 2002).

\section{KESIMPULAN}

Lembaga Kesejahteraan Sosial Anak Dana Mulia adalah lembaga yang bergerak bidang pengasuhan anak terlantar dari berbagai kota di seluruh Indonesia. LKSA tersebut sudah ter akreditasi 'A ' sehingga telah menerapkan layanan sesuai dengan Stadar Nasional Pengasuhan Anak termasuk 
pemenuhan hak Partisipasi Anak. Namun penerapan partipasi anak masih belum optimal yaitu anak hanya terbatas dilibatkan dalam il pengambilan keputusan terkait dengan kehidupannya. Untuk itu telah dilakukan fasilitasi untuk membangun partisipasi anak dengan melibatkan anak-anak menyusun peraturan terkait aktivitas mereka di lembaga. Desain Model Rumah Harapan merupakan alternatif untuk memenuhi hak partisipasi anak di lembaga pengasuhan alternatif. Pada model ini diharapkan partisipasi bukan hanya 'manipulasi' namun dapat mencapai tingkat patisipasi yang tinggi dimana anak-anak dapat berinisiatif dan orang dewasa mendengarkan dan mendiskusikan serta memenuhi pilihan dan suara anak sesuai dengan kapasitas lembaga. Untuk meningkatkan partisipasi anak maka disarankan Lembaga Pengasuhan

1. Melakukan peningkatan kapsitas anak untuk asertif menyampaikan pendapatnya

2. Penguatan pengasuh dan petugas untuk mendengarkan dan memahami perkembangan anak

3. Melakukan review terhadap peraturan terkait dengan kehidupan anak di Lembaga Kesejahteraan Sosial Anak

Saran untuk penelitian lanjutan :

1. Melakukan penelitian tentang tingkat partisipasi anak

2. Partisipasi anak di lembaga pendidikan

\section{DAFTAR PUSTAKA}

A.A Anwar Prabu Mangkunegara. 2006. Perencanaan dan. Pengembangan Manajemen Sumber Daya Manusia. Yogyakarta: Pen. PT Refika. Aditama.
Bambang Warsita. 2008. Teknologi Pembelajaran Landasan dan Aplikasinya.Jakarta: Rineka Cipta

Borgne, C. L., \& Tisdall, E. K. (2017). Children's participation: Questioning competence and competencies? Social Inclusion, 5(3), 122-130. doi:http://dx.doi.org/10.17645/si.v5i3.986

Bengry-Howell, A., Wiles, R., Nind, M., \& Crow, G. (2011). A review of the academic impact of three methodological innovations: Netnography, child-led research and creative research methods.

Dubois, Karla. \& Michael. Generalist Social Work Practice Eighth Edition. USA: USA.Pearson

Edi Suharto. 2013. Kebijakan Sosial sebagai Kebijakan Publik. Bandung: Alfabeta Hadari Nawawi. 2017. Perencanaan SDM Untuk Organisasi Profit Yang Kompetitif. Yogyakarta: UGM Press

Ellya Susilowati. 2021. Praktek Pekerjaan Sosial dengan Anak. Stks. Press

Kellett, M. (2012). Child-led research from inception to reception: Methodological innovation and evolution issues. CM Komunikacija i mediji, 7(24), 5-25.

Permensos No 30/HUK/2011 tentang Standar Pengasuhan Anak di LKSA

Susilowati, E., Dewi, K., \& Kartika, T. (2019). Penerapan Standar Nasional Pengasuhan Pada Lembaga Kesejahteraan Sosial Anak Di Provinsi Kalimantan Selatan. Jurnal Ilmiah Kebijakan dan Pelayanan Pekerjaan Sosial, 1(1).

Tali_Gal_International_Perspectives_and_Em pirical. (n.d.).(2015) International Perspectives and Empirical Findings on Child Participation: From Social Exclusion to Child-Inclusive Policies. Oxford University Press

The what, why and how of child ParticipationA review of the conceptualization of "Child participation" in child welfare. (2021). Social Sciences, 10(2), 54. doi:http://dx.doi.org/10.3390/socsci10020 054 
UNICEF (2003). Modul Pelatihan Child Right Convention 